\title{
Temporal variability in abundance of the sea urchins Paracentrotus lividus and Arbacia lixula in the northwestern Mediterranean: comparison between a marine reserve and an unprotected area
}

\author{
Enric Sala ${ }^{1, *}$, Marta Ribes$^{2}$, Bernat Hereu ${ }^{1}$, Mikel Zabala ${ }^{1}$, \\ Victor Alvà $^{2}$, Rafel Coma ${ }^{2}$, Joaquim Garrabou ${ }^{1}$ \\ ${ }^{1}$ Departament d'Ecologia, Facultat de Biologia, Universitat de Barcelona, Diagonal 645, E-08028 Barcelona, Spain \\ ${ }^{2}$ Institut de Ciencies del Mar (CSIC), Passeig Joan de Borbó s/n, E-08039 Barcelona, Spain
}

\begin{abstract}
Sea urchin populations were monitored in the Medes Islands Marine Reserve (NW Mediterranean) and an adjacent unprotected area in order to (1) describe temporal variability in abundance and population size-structure of sea urchins within each area (from 1991 to 1997), and (2) to compare these areas to investigate the role of fish predation level in determining sea urchin population structure over time (from 1995 to 1997). Abundance of the sea urchin Paracentrotus lividus (Lamarck) was monitored at 7 sites ( 4 inside and 3 outside the reserve), and 2 distinct habitats (fields of big boulders and vertical walls). P. lividus exhibited significant variability in density over time on boulders, both inside and outside the reserve, whereas its density did not vary significantly on vertical walls. $P$. lividus populations differed significantly in size-structure across sites, varying from unimodal to bimodal among sites and years. Density and mean size of $P$. lividus were not significantly different between the protected and the unprotected area in either of the 2 habitats. Abundance of the sea urchin Arbacia Iixula (L.) was monitored from 1995 to 1997 on vertical walls and boulders (4 sites inside and 3 sites outside the reserve). Density of $A$. lixula differed significantly over time on boulders, but it did not on walls. On vertical walls, density and mean size of $A$. lixula were not significantly different between areas in both habitats. This study shows that in the Medes Islands region, sea urchins exhibit striking short-term fluctuations in abundance, which can lead to misinterpretation of larger-scale temporal patterns. The comparison between the protected and the unprotected area does not support the hypothesis of fish predation as the most important factor affecting $P$. lividus populations in the Medes Islands, as patterns of lower sea urchin density relative to the unprotected area nearby were not maintained over time. These facts indicate that factors other than fish predation are very important in determining sea urchin population structure in the northwestern Mediterranean.
\end{abstract}

KEY WORDS: Sea urchins - Temporal vanability Marine reserves Fish predation - Mediterranean Paracentrotus Arbacia

\section{INTRODUCTION}

Ecological research suggests that fishing has important effects on the trophic structure of whole ecosystems (e.g. Dayton et al. 1995, Botsford et al. 1997). Research in marine reserves has shown that the return

\footnotetext{
- Present address and address for correspondence: Scripps Institution of Oceanography, University of California at San Diego, La Jolla, California 92093-0201, USA.

E-mail: esala@coast.ucsd.edu
}

to hypothetical former predation levels through prohibition of fishing may have important indirect effects on ecosystem structure through trophic cascades. For example, the recovery of predatory fish within reserves may cause a reduction in sea urchin populations (e.g. McClanahan \& Muthiga 1989, McClanahan \& Shafir 1990). In turn, sea urchins have important roles in determining the structure of alga-dominated benthic communities (see reviews by Lawrence 1975 and Schiel \& Foster 1986). In the Mediterranean, the sea urchin Paracentrotus lividus (Lamarck) is a key 


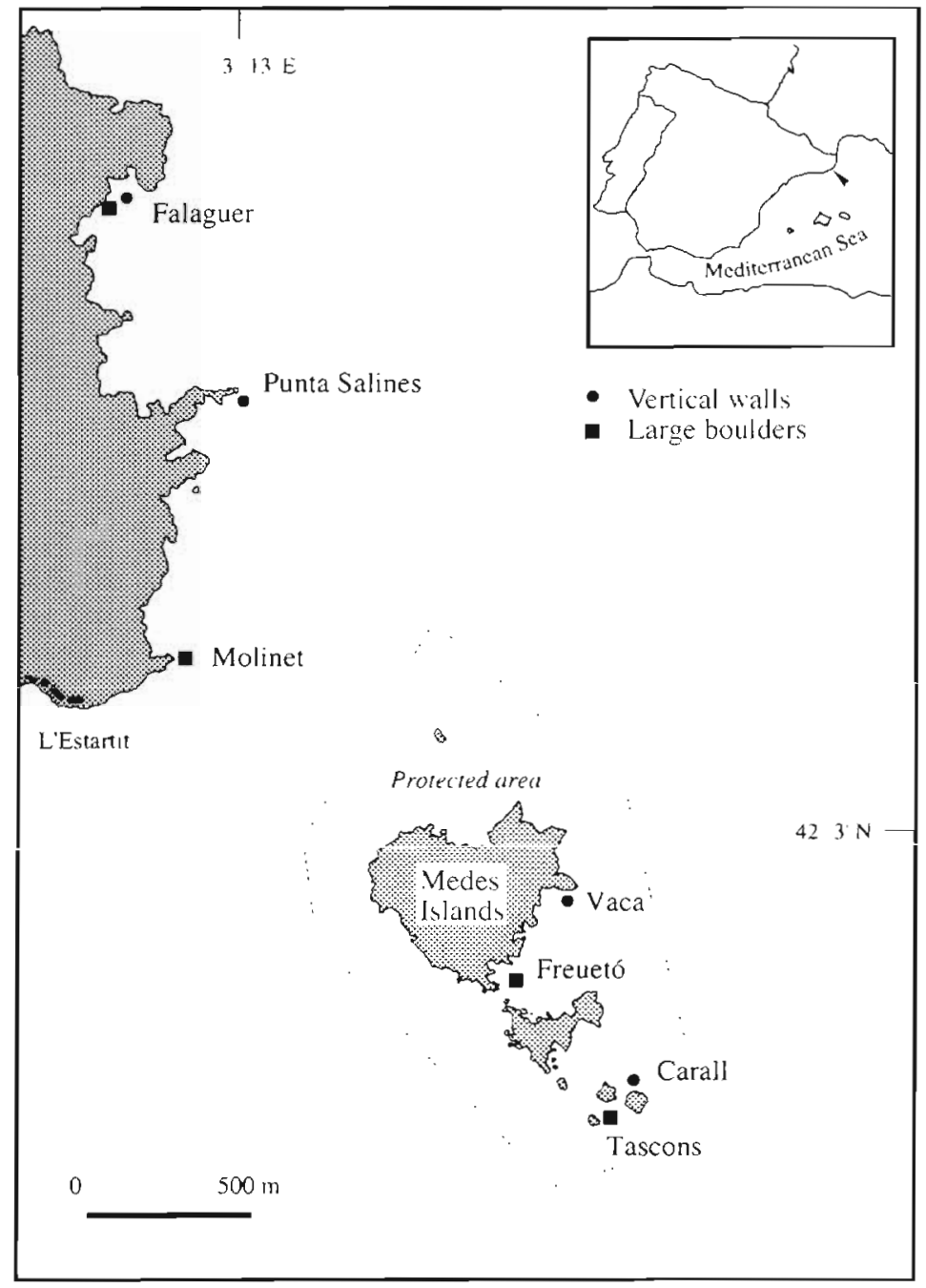

Fig. 1. Location of study sites, inside (Tascons, Freuetó, Vaca and Carall) and outside (Falaguer, Molinet, and Punta Salines) of the Medes Islands Marine Reserve, NE Spain, northwestern Mediterranean Sea. Dashed line represents the limits of the Marine Reserve, where all fishing is prohibited
In a previous study, Sala \& Zabala (1996) monitored the abundance of Paracentrotus lividus within and outside the Medes Islands Marine Reserve (NE Spain) for $3 \mathrm{yr}$ (1992 to 1994), reporting a pattern of lower abundance of sea urchins in the reserve relative to nearby unprotected areas. This pattern was attributed to differences in predatory fish abundance between the reserve and the unprotected area (GarcíaRubies \& Zabala 1990, García-Rubies 1997). Higher abundances of predatory fish in the reserve have been maintained over time (García-Rubies 1997); have decreased sea urchin abundances been maintained as well? Sea urchin populations may exhibit significant variations in density over time due to several factors, including recruit ment and disease (Lawrence \& Sammarco 1982, Lessios 1988, Lawrence 1996). Thus, long-term monitoring of sea urchin populations is important for distinguishing changes in abundance due to natural fluctuations, long-term oceanographic processes, and anthropogenic impacts. The aims of this study were: (1) to describe temporal variability (from 1991 to 1997) in abundance and population size-structure of the sea urchins $P$. lividus and Arbacia lixula in some rocky habitats in the northwestern Mediterranean, and (2) to make comparisons among protected and unprotected areas from 1995 to 1997 to investigate the role of fish predation level in determining sea urchin population structure over time (sea urchin harvesting in this region is low, and thus we hypothesize that differences between areas may be caused by differences in predatory fish abundance).

\section{MATERIAL AND METHODS}

species that at high densities influences the dynamics of the phytobenthos, by eliminating erect algae and seagrasses, and inducing the formation of coralline barrens (Verlaque \& Nédélec 1983, Verlaque 1987), but that also exerts a significant effect on algal assemblage structure at low densities (Palacín et al. in press). The sea urchin Arbacia lixula (L.) generally avoids large erect algal assemblages, focusing its grazing activity mainly on encrusting algae (Kempf 1962). It has been suggested that $A$. lixula probably benefits from prior removal of erect algae by $P$. lividus (Frantzis et al. 1988). Therefore, knowledge of the effects of fishing on sea urchin populations is of fundamental importance in ecosystem management (McClanahan 1994. McClanahan \& Sala 1997).
The study was carried out in the Medes Islands Marine Reserve and a nearby unprotected area (NE Spain, northwestern Mediterranean Sea) (Fig. 1). The Marine Reserve (created in 1983), where fishing is prohibited $(93.2 \mathrm{ha})$, is located $1 \mathrm{~km}$ offshore from the town of L'Estartit $\left(42^{\circ} 16^{\prime} \mathrm{N}, 03^{\circ} 13^{\prime} \mathrm{E}\right)$ and encompasses a group of small islands (total surface area less than 20 ha). The study was conducted within 2 habitats: (1) fields of large limestone boulders (Tascons and Freuetó, within the reserve, hereafter ' $R$ '; Falaguer and Molinet, outside the reserve, hereafter ' $N R$ ') and (2) vertical walls (Carall and Vaca, $R$; Punta Salines and 
Falaguer, NR) (Fig. 1). Boulder habitats were colonized by a rich algal assemblage dominated by erect algae, articulated calcareous algae and small filamentous algae (Sala \& Boudouresque 1997). Vertical walls supported algal assemblages as well as numerous suspension feeders (Ros et al. 1985).

Abundance and population size-structure of sea urchins were studied by SCUBA diving along randomly located transects (50 $\times 1 \mathrm{~m}$ each) on bottoms between 5 and $10 \mathrm{~m}$ depth, at each study site. Transects were divided into five $10 \mathrm{~m}^{2}$ subtransects. Within the first $20 \mathrm{~m}^{2}$ of each transect, Paracentrotus lividus $>1 \mathrm{~cm}$ in diameter were counted and their diameter (test without spines) measured with calipers. In the remaining $30 \mathrm{~m}^{2}, P$. lividus were counted but not measured. Since Arbacia lixula density was lower, all individuals $>1 \mathrm{~cm}$ in diameter were counted and measured within the transects. Diameters were grouped in size classes of $1 \mathrm{~cm}$, and in subtransects of $10 \mathrm{~m}^{2}$. Sampling ( 3 to 5 transects per site and date) was carried out once per summer. P. lividus was monitored from 1991 to 1997 in Tascons (R), Freuetó (R), Carall (R), and Punta Salines (NR), from 1992 to 1997 in Falaguer (NR), and from 1995 to 1997 in Vaca ( $R$ ) and Molinet (NR). A. lixula was monitored from 1995 to 1997 in all of the above sites. Since only one sampling could be done yearly due to logisticul constraints, wo decided to sample always during the same season (summer), in part because $P$. lividus shows recruitment peaks at this time (Lozano et al. 1995, Sala \& Zabala 1996), and thus we expected to visually find $1 \mathrm{yr}$ old individuals in our transects 1 yr after they settled. To test for temporal variability in density and mean size within sites, 1-way ANOVAs were performed on log-transformed data.

In 1995 we decided to study the effect of the protected area (i.e. the effect of high density of predatory fish) on sea urchin populations, and thus added new sampling sites to the monitoring program, in order to account for spatial heterogeneity within areas. A hierarchical sampling design (at least 2 sites within each of the areas) was needed to properly test differences in density and mean size of Paracentrotus lividus and Arbacia lixula between protected and unprotected areas. To test for differences in density and mean size between areas (protected vs unprotected), ANOVAs were performed on logtransformed data between 1995 and 1997, where data were available for 2 sites inside the reserve and 2 sites outside the reserve. Within this analysis, site (random factor) was nested within the level of protection (fixed factor; protected or unprotected) in order to account for the differences between areas.

\section{RESULTS}

\section{Temporal variability in Paracentrotus Iividus populations}

Densities of Paracentrotus lividus for all sampling dates and sites are shown in Fig. 2. In Tascons (R), density steadily increased from 1991 to 1995, then decreased until 1997 ( 1 -way ANOVA, df $=6, F=5.78$. $\mathrm{p}<0.001)$. In Freuetó (R), density also varied significantly over time ( $\mathrm{df}=6, F=6.32, \mathrm{p}<0.001)$, dropping by a factor of 2 from 1991 to 1992, then remained stable until 1994, when it increased by a factor of 2 . Between 1995 and 1997 densities at Freuetó showed smaller fluctuations. In Falaguer (NR), density exhibited a significant increase from 1992 to 1993, but after
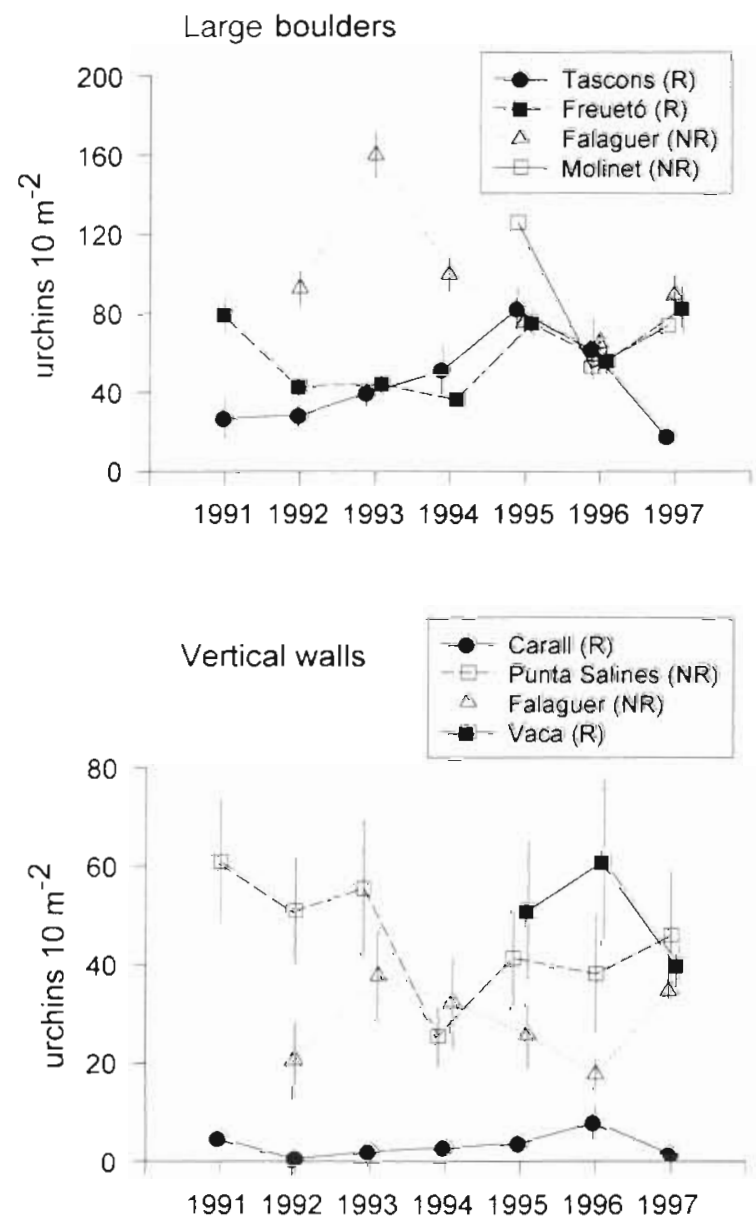

Fig. 2. Paracentrotus lividus. Number of sea urchins $(>1 \mathrm{~cm}$ diameter) per $10 \mathrm{~m}^{2}$ (mean $\pm \mathrm{SE}$ ) at each site and in the 2 types of habitats studied (large boulders and vertical walls, between 5 and $10 \mathrm{~m}$ depth) during the monitoring period (1991 to 1997). Solid symbols represent sites within the Medes Islands Marine Reserve (R); open symbols represent sites in the nearby unprotected, fished area (NR) 
$1993 P$. lividus numbers exhibited a continuous decrease until 1996, and then increased slightly in 1997 ( $\mathrm{df}=5, F=13.30, \mathrm{p}<0.001)$. In Molinet (NR), density dropped from 1995 to 1996 , then increased slightly (df $=2, F=8.07, \mathrm{p}=0.001)$.

On vertical walls, Paracentrotus lividus populations showed statistically significant variations in density only within Carall (R), where density exhibited a 16-fold increase from 1992 to 1996 (Fig. 2; 1-way ANOVA, $\mathrm{df}=6, F=2.20, \mathrm{p}<0.05$ ). The higher variance observed on vertical walls relative to big boulders indicates that spatial heterogeneity at the $10 \mathrm{~m}^{2}$ scale is higher on vertical walls, i.e. P. lividus are more evenly distributed on big boulders than on vertical walls.

\section{Tascons $(R) \quad$ Freuetó $(R) \quad$ Molinet $(N R)$}

\section{Falaguer (NR)}
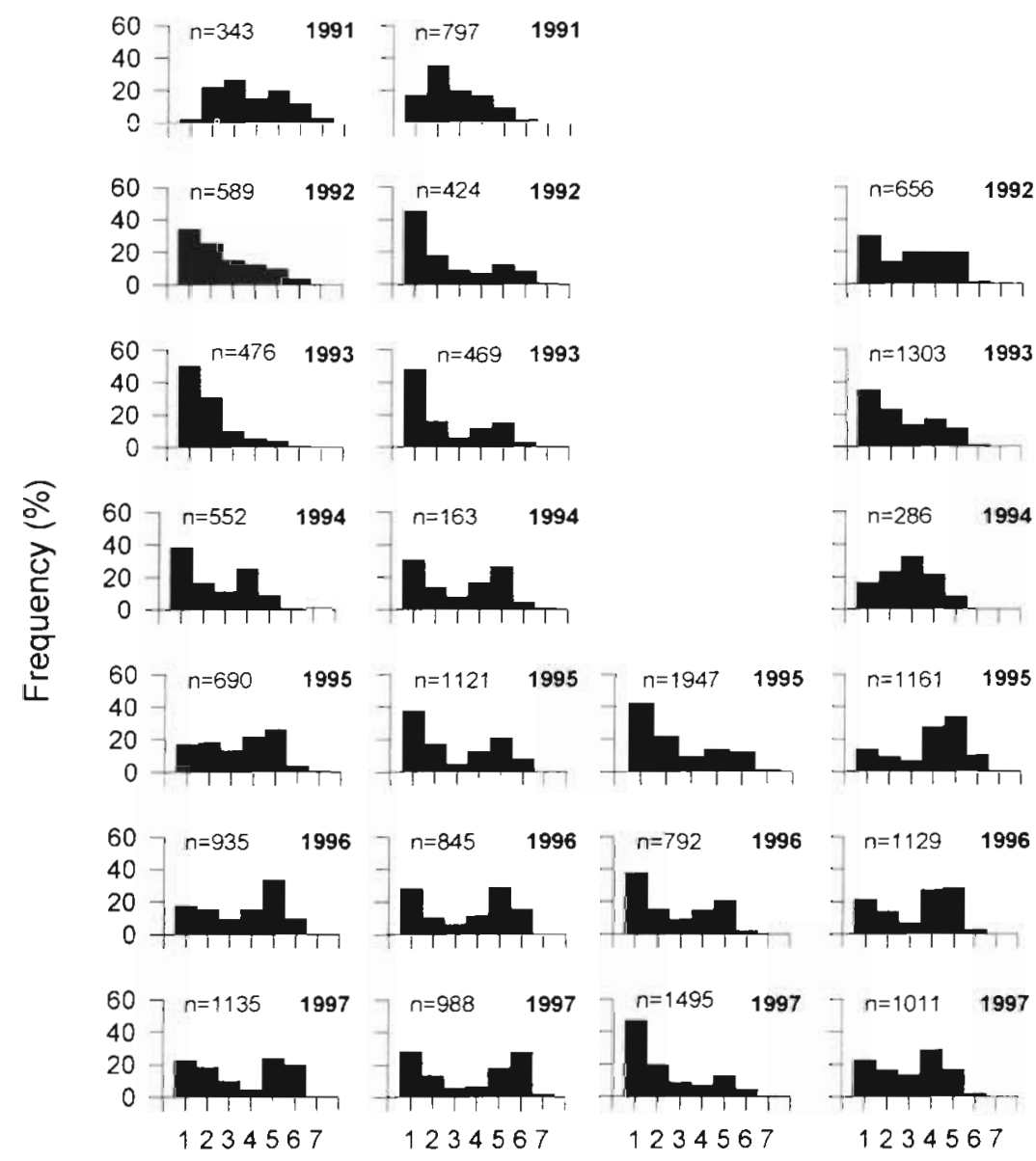

Size Class $(\mathrm{cm})$

Fig. 3. Paracentrotus lividus. Sea urchin ( $>1 \mathrm{~cm}$ ) test size frequency from 1991 to 1996 on large boulders (between 5 and $10 \mathrm{~m}$ depth) within (Tascons and Freuetó) and outside (Falaguer and Molinet) the Medes Islands Marine Reserve. Size classes: $1=1-1.9 \mathrm{~cm}, 2=2-2.9 \mathrm{~cm}, 3=3-3.9 \mathrm{~cm}, 4=4-4.9 \mathrm{~cm}, 5=$ $5-5.9 \mathrm{~cm}, 6=6-6.9 \mathrm{~cm}, 7=7-7.9 \mathrm{~cm}$
At Tascons ( $\mathrm{R}$ ), mean size of Paracentrotus lividus varied significantly over time (1-way ANOVA, df $=6$, the size distribution at Tascons (Fig. 3). The size-frequency graphs illustrate an exponential decrease from 992 to 1993. After 1993, however the distribution was recruitment rate during these years. At Freuetó (R) mean size also varied significantly over time ( $\mathrm{df}=6$, $F=34.29, \mathrm{p}<0.001)$. High recruitment rates in 1992 duced a size-distribution with a very conspicuous mode of small urchins (Fig. 3). However, as recruitment declined after 1993, the size distribution was markedly bimodal, with a first mode composed of small urchins (1 to $2 \mathrm{~cm}$ ) and a second mode of individuals of 5 to $6 \mathrm{~cm}$ diameter. At Molinet (NR): where mean size varied significantly from 1995 to 1997 (df $=2$, $F=15.43, p<0.001$ ), small urchins were the most abundant, probably responding to good recruiment during these years. Falaguer (NR) showed a pulse of recruits in 1992 and 1993, but after 1993 recruitment was lower and the sea urchin population showed abundance peaks at larger sizes as the study progressed ( $\mathrm{df}=5, F=$ 52.65, $\mathrm{p}<0.001$ ).

Mean size of Paracentrotus lividus did not vary significantly over time at Carall (R) (1-way ANOVA, df =6, F = $1.90, p=0.129)$. At this site, no small urchins (less than $2 \mathrm{~cm}$ in diameter) were found until 1994 (Fig 4). From 1991 to 1993 , the size distribution was skewed towards large size-classes, with a peak at 5 to $6 \mathrm{~cm}$ diameter. Low recruitment occurred every year, however, after 1993. The peak of urchins of 5 to $6 \mathrm{~cm}$ diameter was maintained during the 7 years of the study, except in 1994 when the population peaked at 2 to $3 \mathrm{~cm}$, and in 1997 when the distribution was bimodal, with a second peak of urchins at 2 to $3 \mathrm{~cm}$. At Vaca (R), where mean size varied significantly over time ( $\mathrm{df}=2$, $F=15.99, \mathrm{p}<0.001$ ), small urchins $(<2 \mathrm{~cm})$ were the most abundant between 1994 and 1997, especially in 
1995, where half of the total number of urchins were small (Fig. 4). The distribution was bimodal from 1995 to 1997 , with a second mode at 5 to $6 \mathrm{~cm}$. At Punta Salines (NR), the size distributions indicated variations in population size over time (Fig. 4 ; $\mathrm{df}=6, F=30.99$, $\mathrm{p}<0.001$ ). In 1991 the size distribution was bimodal, with a first mode comprised of small urchins and a second mode of large urchins 6 to $7 \mathrm{~cm}$ in diameter. In 1993 the pattern was blurred, and low recruitment occurred every year from 1993 to 1997, with the major pattern in size distribution being an accumulation of individuals in larger size-classes. At Falaguer (NR), the size distributions were skewed, with few small individuals and a mode of urchins between 4 and $6 \mathrm{~cm}$ in diameter (Fig. 4). Although mean size differed significantly over time ( $\mathrm{df}=5, F=8.74, \mathrm{p}<0.001)$, this pattern was maintained from 1992 to 1997.

\section{Comparison of Paracentrotus lividus populations among areas}

Comparison of Paracentrotus lividus densities on large boulders from 1995 to 1997 showed significant differences in density among sites within areas (Table 1a). Mean density did not differ between the protccted and the unprotected area. There was a significant variation in density over time, but temporal trends were not significantly different among areas. Comparison of densities on vertical walls (1995 to 1997) showed a different pattern (Fig. 2, Table 1b). Although there were no significant differences in density over time, density varied significantly among sites within areas, where differences among sites were higher inside than outside the reserve. However, density did not differ significantly between the protected area and the unprotected area from 1995 to 1997

Comparison of mean size of Paracentrotus lividus on large boulders showed significant differences over time, and among sites within areas (Fig. 3, Table 2a). However, there were no significant differences between the protected and the unprotected area. On vertical walls, the comparison of mean size of $P$. lividus showed significant differences over time, and among sites within areas (Fig. 4, Table 2b), but, as on large boulders, mean size did not differ significantly between the protected and the unprotected area.

\section{Temporal variability in Arbacia lixula populations}

Densities of Arbacia lixula for all sampling sites and dates are shown in Fig. 5. Densities on large boulders showed significant differences over time (from 1995 to 1997; Table 3a). Density did not change at Tascons (R) from 1995 to 1997 (Fig. 5; 1-way ANOVA, df =2, F= $0.98, \mathrm{p}=0.38$ ) or at Molinet $(\mathrm{NR})(\mathrm{df}=2, F=2.05, \mathrm{p}=$ $0.13)$. At Freuetó (R), density significantly varied from 1996 to 1997 , where mean density increased by 3 times ( $\mathrm{df}=2, F=6.79, p<0.001)$. At Falaguer (NR), density increased steadily from 1995 to 1997 ( $\mathrm{df}=2, F=4.34$, $\mathrm{p}=0.019$ ). On vertical walls, density did not vary

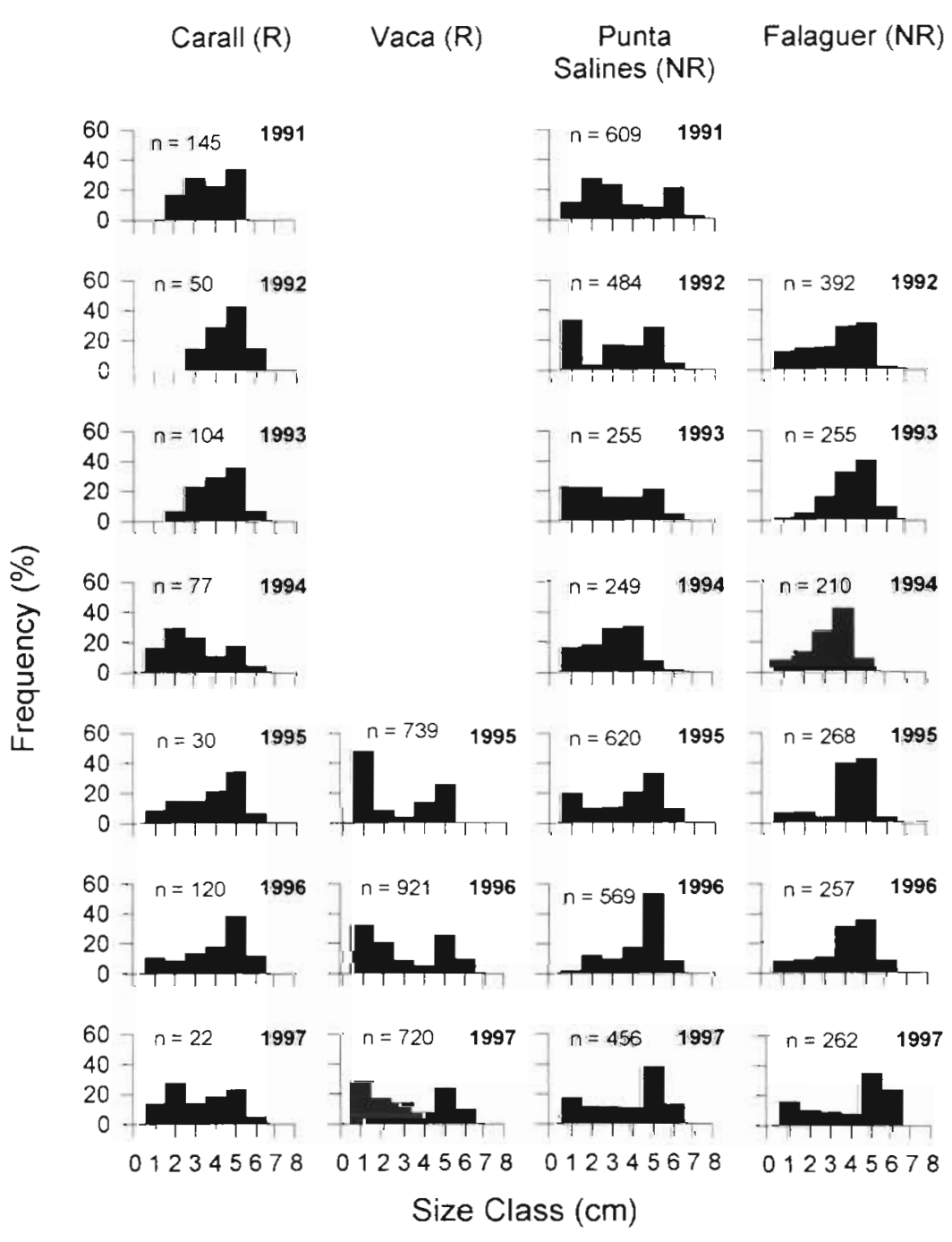

Fig. 4. Paracentrotus lividus. Sea urchin $(>1 \mathrm{~cm}$ ) test size frequency from 1991 to 1996, on vertical walls (between 5 and $10 \mathrm{~m}$ depth) within (Carall and Vaca) and outside (Falaguer and Punta Salines) the Medes Islands Marine Reserve. Size classes as in Fig. 3 
Table 1 Density of Paracentrotus lividus. Results of nested ANOVA comparing densities between protected and unprotected areas and over time (1995 to 1997) on (a) large boulders and (b) vertical walls

\begin{tabular}{|lrrrc|}
\hline Factor & df & MS & $F$ & $p$ \\
\hline (a) Large boulders & & & & \\
Time & 2 & 0.68 & 11.31 & $<0.001$ \\
Area & 1 & 0.82 & 1.84 & 0.308 \\
Site(Area) & 2 & 0.44 & 7.38 & 0.001 \\
Area $\times$ Time & 2 & 0.16 & 2.59 & 0.078 \\
Error & 170 & 0.06 & & \\
(b) Vertical walls & & & & \\
Time & 2 & 0.01 & 0.08 & 0.92 \\
Area & 1 & 0.83 & 0.25 & 0.667 \\
Site(Area) & 2 & 3.32 & 33.54 & $<0.001$ \\
Area $\times$ Time & 2 & 0.15 & 1.49 & 0.23 \\
Error & 173 & 0.10 & & \\
& & & & \\
\hline
\end{tabular}
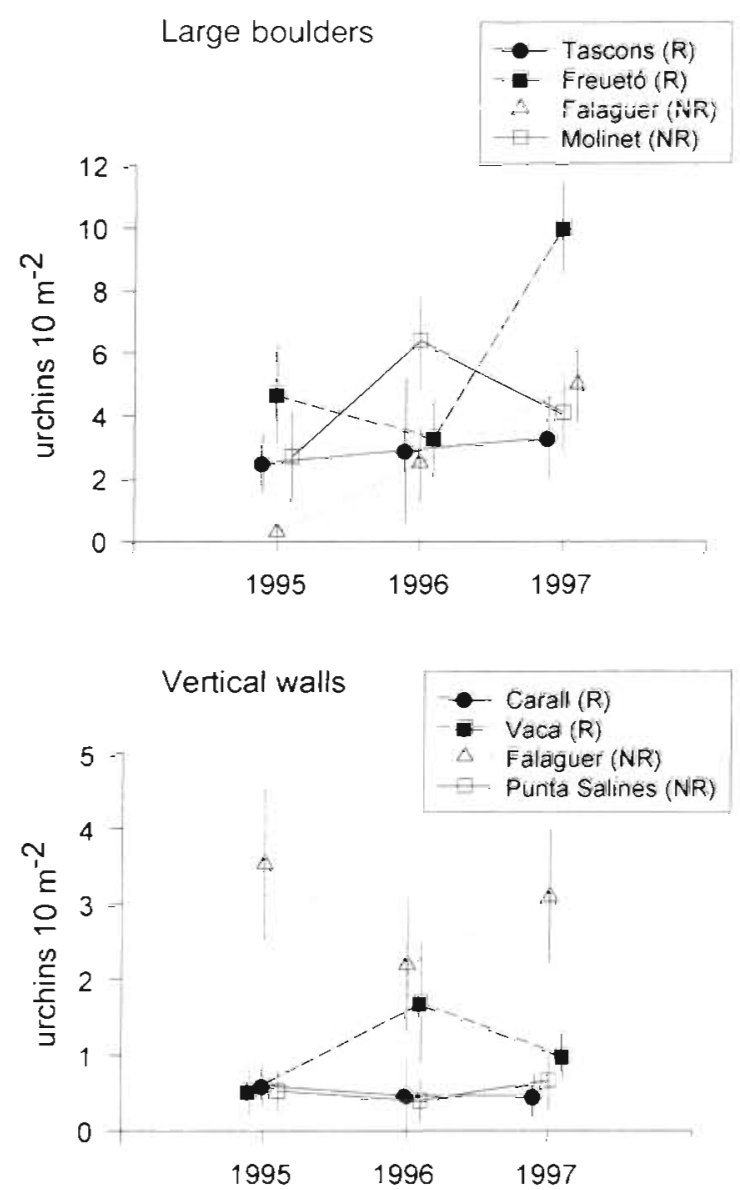

Fig. 5. Arbacia lixula. Number of sea urchins ( $>1 \mathrm{~cm}$ diameter) per $10 \mathrm{~m}^{2}$ (mean $\pm \mathrm{SE}$ ) at each site and in the 2 types of habitats studied (large boulders and vertical walls, between 5 and $1.0 \mathrm{~m}$ depth) during the monitoring period. Solid symbols represent sites within the Medes Islands Marine Reserve (R); open symbols represent sites in the nearby unprotected, fished area (NR)
Table 2. Size of Paracentrotus lividus. Results of nested ANOVA comparing mean size between protected and unprotected areas and over time (1995 to 1997) on (a) large boulders and (b) vertical walls

\begin{tabular}{|lrrrr|}
\hline Factor & df & MS & $F$ & $p$ \\
\hline (a) Large boulders & & & & \\
Time & 2 & 0.73 & 18.97 & $<0.001$ \\
Area & 1 & 4.81 & 0.38 & 0.601 \\
Site(Area) & 2 & 12.67 & 328.62 & $<0.001$ \\
Area $\times$ Time & 2 & 2.89 & 75.08 & $<0.001$ \\
Error & 3241 & 0.04 & & \\
(b) Vertical walls & & & & \\
Time & 2 & 1.21 & 34.33 & $<0.001$ \\
Area & 1 & 2.61 & 2.94 & 0.229 \\
Site(Area) & 2 & 0.89 & 25.21 & $<0.001$ \\
Area $\times$ Time & 2 & 0.39 & 11.06 & $<0.001$ \\
Error & 4976 & 0.04 & & \\
& & & & \\
\hline
\end{tabular}

Table 3. Density of Arbacia lixula. Results of nested ANOVA comparing densities between protected and unprotected areas and over time (1995 to 1997) on (a) large houlders and (b) vertical walls

\begin{tabular}{|lrrrr|}
\hline Factor & df & MS & $F$ & \multicolumn{1}{c|}{$p$} \\
\hline (a) Large boulders & & & & \\
Time & 2 & 1.43 & 8.97 & $<0.001$ \\
Area & 1 & 0.33 & 0.22 & 0.685 \\
Site(Area) & 2 & 1.49 & 9.32 & $<0.001$ \\
Area $\times$ Time & 2 & 0.96 & 6.02 & 0.003 \\
Error & 172 & 0.16 & & \\
(b) Vertical walls & & & & \\
Time & 2 & 0.02 & 0.25 & 0.777 \\
Area & 1 & 0.49 & 0.45 & 0.571 \\
Site(Area) & 2 & 1.10 & 12.08 & $<0.001$ \\
Area $\times$ Time & 2 & 0.07 & 0.77 & 0.466 \\
Error & 172 & 0.09 & & \\
& & & & \\
\hline
\end{tabular}

significantly over time at any of the sites (1-way ANOVA, $p>0.05$ ).

On large boulders there were no significant differences in Arbacia lixula mean size over time. All sites showed a dominance of individuals $>3 \mathrm{~cm}$, with the sites in the unprotected area showing a strong peak at 4 to $5 \mathrm{~cm}$. The size-frequency distributions at Tascons and Freuetó (R) between 1995 and 1996 reflect low recruitment of $A$. lixula. Falaguer and Molinet (NR) exhibited a very narrow unimodal. distribution in 1995 and 1996 (Fig. 6). Only individuals between 3 and $5 \mathrm{~cm}$ diameter were found at this time, suggesting a lack of recruitment in preceding years. However, the size distribution in 1997 indicates a low recruitment. Only Freuetó (R) showed significant variations on 
mean size over time (1-way ANOVA, $\mathrm{df}=2, F=6.79, \mathrm{p}=0.001$ ).

Mean size did not vary significantly over time at any site on vertical walls (1-way ANOVA, p > 0.05). All sites showed a unimodal size-distribution, with a peak at 4 to $6 \mathrm{~cm}$ diameter (Fig. 7 ). Small individuals $(<2 \mathrm{~cm})$ were only detected at Punta Salines (NR) in 1996 and Vaca (R) in 1997. Aside from these 2 sites, the remaining sites and years showed a consistent pattern of dominance of large individuals and lack of recruitment.

\section{Comparison of Arbacia lixula populations among areas}

On large boulders, there were no significant differences in Arbacia lixula density between the reserve and the unprotected area (Fig 5, Table 3a). However, there were significant differences among sites within areas, although significant differences were detected only among the sites inside the reserve (Tukey's test, $p=0.03$ ). On vertical walls, there were significant differences in density among sites within areas (Fig. 5, Table 3b); in this case, density was significantly different among sites in the unprotected area (Tukey's test, $p=0.006$ ). However, there were no significant differences in density between areas or over time.

The comparison of sizes of Arbacia lixula on large boulders showed no significant differences among sites within areas, or among areas (Fig, 6, Table 4a).

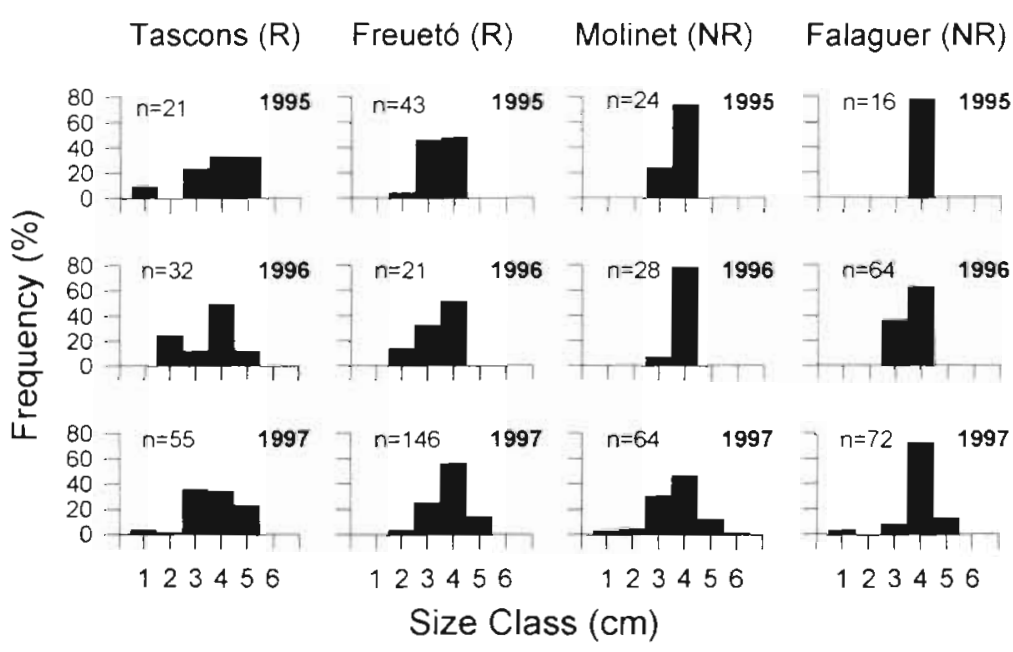

Fig. 6. Arbacia lixula. Sea urchin $(>1 \mathrm{~cm})$ test size frequency from 1995 to 1997 on large boulders (between 5 and $10 \mathrm{~m}$ deep), within (Tascons and Freueto) and outside (Falaguer and Molinet) the Medes Islands Marine Reserve. Size classes as in Fig. 3
On vertical walls, the comparison of mean size of $A$. lixula across sites showed significant differences among sites within areas, but there were no significant differences among areas (Fig. 7, Table 4b).

\section{DISCUSSION}

\section{Paracentrotus lividus populations}

Fishing pressure on sea urchin predators (mostly fin fish) has been identified as a major factor in determining the abundance of sea urchins in sublittoral communities (Tegner \& Dayton 1981, Breen et al. 1982, Cowen 1983, Hay 1984). Comparisons of marine reserves (where fishing is prohibited) and unprotected areas have shown a general pattern of lower sea urchin abundance within marine reserves in tropical (McClanahan \& Muthiga 1989, McClanahan \& Shafir 1990, McClanahan 1995) and temperate (Boudouresque et al. 1992, San Martin 1995, Sala \& Zabala 1996) seas. Most studies conducted in temperate seas, however, carried out short-term comparisons (up to $3 \mathrm{yr}$ ) between protected and unprotected areas. In the Medes Islands Marine Reserve, fish density was higher than in nearby unprotected areas for 8 yr (1989 to 1996; García-Rubies \& Zabala 1990, García-Rubies 1997), and density of the sea urchin Para- 
Table 4. Size of Arbacia lixula. Results of nested ANOVA comparing mean size between protected and unprotected areas and over time (1995 to 1997) on (a) large boulders and (b) vertical walls

\begin{tabular}{|c|c|c|c|c|}
\hline Factor & $\mathrm{df}$ & MS & $F$ & $\mathrm{p}$ \\
\hline \multicolumn{5}{|c|}{ (a) Large boulders } \\
\hline Time & 2 & 0.010 & 1.58 & 0.207 \\
\hline Area & 1 & 0.040 & 12.42 & 0.072 \\
\hline Site(Area) & 2 & 0.003 & 0.50 & 0.609 \\
\hline Area $\times$ Time & 2 & 0.018 & 2.77 & 0.064 \\
\hline Error & 516 & 0.007 & & \\
\hline \multicolumn{5}{|c|}{ (b) Vertical walls } \\
\hline Time & 2 & 0.001 & 0.34 & 0.714 \\
\hline Ared & 1 & 0.018 & 0.75 & 0.477 \\
\hline Site(Area) & 2 & 0.024 & 5.60 & 0.004 \\
\hline Area $\times$ Time & 2 & 0.005 & 1.26 & 0.287 \\
\hline Error & 222 & 0.004 & & \\
\hline
\end{tabular}

centrotus lividus was lower (3 times) between 1992 and 1994 (Sala \& Zabala 1996). The present study shows that after 1994 an increase in density within the reserve coupled with a decrease in density outside the reserve led to similar sea urchin abundances on boulders between the 2 areas. The size distributions suggest that the strong increase in $P$. lividus abundance in boulder habitat at Falaguer (NR) from 1992 to 1993 was due to the 1992 extraordinary recruitment episode (when $P$. lividus $<1 \mathrm{~cm}$ were found at an average density of 1160 ind. $\mathrm{m}^{-2}$ at this site; Sala \& Zabala 1996) whereas the later decrease until 1996 was coupled to lower recruitment rates. On vertical walls, the addition of a new sampling site within the reserve (Vaca) showed strong spatial heterogeneity, because $P$. lividus densities at this site were higher than at any other site, including those outside the reserve. That also restilted in lack of significant differences in density between the protected and the unprotected area on walls.

Differences in density among sites within areas for both habitats suggest that differences in microhabitat features, recruitment rate, and/or fish predation rate might exist at a scale of hundreds of meters. Sala \& Zabala (1996) reported significant differences in recruitment rate between 2 sites on boulders inside the reserve (Tascons and Freuetó) located $500 \mathrm{~m}$ apart. Likewise, fish densities were different among sites within the reserve (Garcia-Rubies 1997), which can result in different predation rates. Sites were selected for similar substrate, size of boulders, orientation, and water motion, but unnoticed differences in microhabitat (such as microshelters) might result in differences in survival rate of recruits.

Bimodal size distributions in sea urchin populations have been attributed to several factors, including inter- annual variability in recruitment rate (Underwood \& Fairweather 1989), predation (Tegner \& Dayton 1981. Sala \& Zabala 1996) and accumulation of large yearclasses where longevity is high (Himmelman et al. 1983). In our study, the alternation between uni- and bimodal distribution may be due to all 3 factors. First, high recruitment rates imply a mode of small urchins. A high recruitment episode would be recognizable as a peak in the size distribution traveling through time. Second, when predation is high, early mortality could impact small sea urchins, with no expression of recruitment episodes in later years, resulting in decreasing size distributions (Sala \& Zabala 1996). However, a second mode formed by large individuals may be explained by a change in vulnerability of sea urchins to predation (e.g. when they reach a size at which they leave shelters; Tegner \& Dayton 1981). Paracentrotus lividus attains an escape in size between 4 and $5 \mathrm{~cm}$ (Sala 1997). Third, P. lividus exhibits asymptotic growth (Azzolina 1988), and thus large size-classes are actually formed by several age-classes. Therefore, when longevity is increased (hy low predation rates or by attaining an escape in size) the largest sea urchins accumulate in a second mode. To ascertain the relative importance of these factors would require further study.

At most sites on vertical walls (except Vaca), both within and outside the reserve, and at most times, the size distributions showed modes for large size-classes, suggesting that recruitment was low in this habitat. Vertical walls are a habitat where physical factors may be more important in determining the structure of sea urchin populations. The availability of shelters is meager on vertical walls, and therefore both topography and exposure to predators may contribute to the lower numbers of Paracentrotus lividus populations within the reserve. The maintenance of densities may thus be explained by adult immigration. Immigration at Carall (R) was important during the monitoring period, since $P$. lividus density increased by a factor of 4 in only $1 \mathrm{yr}$ (from 1992 to 1993), without signs of apparent recruitment. Although recruitment of $P$. lividus occurs within this depth range $(5$ to $10 \mathrm{~m}$ ) (Lozano et al. 1995, Sala \& Zabala 1996), immigration of adult urchins may be important in determining the population structure (Azzolina 1988), as on vertical walls within our study sites. Outside the reserve (Punta Salines), recruitment occurred regularly, as evidenced by addition of small individuals to the population. The Vaca (R) site also showed a dominance of small individuals through most of the study period, coupled to a very high density. Later examination of the site showed that Vaca has a high amount of suitable microhabitat for juveniles (small crevices and holes). This suggests that shelters, favoring the survival of high numbers of small individ- 
uals at sites with high fish predation pressure, are also important in determining population structure of $P$. lividus.

Interpretation of the size distribution results may be biased by the fact that growth rate of Paracentrotus lividus may not be the same for all individuals of a cohort. Indeed, $P$. lividus exhibited density-dependent growth rates in the first years when held in an aquarium (Grosjean et al. 1996). If density-dependent growth rates also occur in the field, small sea urchins sheltered in small crevices may have reduced growth rates and therefore not all individuals from a single settlement episode could be detected as recruits at the same time. Therefore, our assumptions concerning recruitment could be biased with regard to the size at which we recorded recruits. However, recruitment episodes of $P$. lividus can be very intense, and we detected an increase in the smallest sizes in boulders 1 yr after a large recruitment episode [that of 1992 , when Sala \& Zabala (1996) monitored the appearance of smallest recruits]. Thus, we assume that even if an unknown number of sea urchins were not detected the first year after settlement, we were still able to detect and estimate the intensity of such settlement episodes from the abundance of the smallest sea urchins.

The behavior of urchins appears to be a good indicator of local predation rate: sea urchins exhibit cryptic behavior, sheltering in the presence of predators, and foraging in exposed sites when predators are absent (Tegner \& Dayton 1981, Cowen 1983, McClanahan \& Kurtis 1991). Paracentrotus lividus also adopts this predator avoidance strategy, sheltering during daylight and grazing away from shelters at night (Kempf 1962, Dance 1987). During the day in the Medes Islands Reserve most $P$. lividus are sheltered, whereas they occupy exposed sites outside the reserve (Sala \& Zabala 1996). We therefore suggest that density alone may not be a good indicator of predation level in habitats with a high availability of shelters, because sea urchin densities may be similar in fished and unfished areas, but the actual urchin stock available to predatory fish (i.e. in exposed sites) can be much lower within reserves. In that case, the combined study of density, size distribution, and spatial distribution of urchins seems more appropiate.

\section{Arbacia lixula populations}

The urchin Arbacia lixula dramatically increased (more than 10-fold) its abundance in western Mediterranean waters from 1983 to 1992 (Francour et al. 1994). Francour et al. (1994) hypothesized that this increase was due to an increase in seawater temperature in shallow waters over the last 20 уг. The densities found during this study were, on average, lower (3.99 ind. per $10 \mathrm{~m}^{2}$ on boulders, 1.27 ind per $10 \mathrm{~m}^{2}$ on vertical walls; range between 0.3 and 10 ind. per $10 \mathrm{~m}^{2}$ ) than those reported at Corsica $\left(10 \mathrm{~A}\right.$. lixula per $10 \mathrm{~m}^{2}$; Francour et al. 1994). However, Kempf (1962) found densities greater than 10 ind. $\mathrm{m}^{-2}$ in Marseille (France) in the early 1960s, which suggests that long-term fluctuations in A. lixula abundance have occurred.

Fenaux \& Pedrotti (1988) found planktonic larvae of Arbacia lixula in areas far from the coast. Further, $A$. lixula larvae are extremely rare along the Catalan coast (X. Turon pers. comm.). These facts and the accumulation of large size-classes at our study sites suggest that recruitment of $A$. lixula may not be annual. A similar pattern was found by Kempf (1962) in Marseille, with a lack of individuals $<3 \mathrm{~cm}$ in diameter, and a peak between 4 and $5.5 \mathrm{~cm}$. One of us (E.S.) found $A$. lixula juveniles $(<1 \mathrm{~cm}$ in diameter) in the Cabrera National Park (Balearic Islands, Spain) in May 1996, beneath rocks in the first meter of water in a sheltered bay. This suggests that recruitment areas may be restricted, and that arrival of individuals could be mainly via immigration of adults from nursery areas. Our data show, nonetheless, that low recruitment occurred in the boulder habitat studied.

Arbacia lixula is seldom found in fish gut contents (Savy 1987, Sala 1996), and it appears to have morphological adaptations (better attachment to substrate, denser spines) that make it less susceptible to fish predation than Paracentrotus lividus (E. Sala unpubl. data). Furthermore, adult $A$. lixula are almost always found at exposed sites, independent of predatory fish abundance. We suggest that $A$. lixula may not be a good indicator of the 'reserve effect', although there might be untested, indirect effects associated with reduction of $P$. lividus density due to fish predation. Therefore, we are not able to fully discuss the lack of differences in density and mean size of $A$. lixula between the protected and the unprotected area.

\section{Conclusions: fish predation and temporal dynamics of sea urchin populations}

Paracentrotus lividus exhibited significant variability in density and mean size over short time scales at most sites. Arbacia lixula only showed such dramatic changes over small time scales on boulders, while populations on walls were more stable. Our results indicate that sea urchin populations in infralittoral bottoms in the northwestern Mediterranean are very dynamic, and that a long-term perspective is needed in order to draw conclusions from comparisons between areas with different levels of fishing. Our results do not support the hypothesis of predation as the most important 
factor affecting $P$. lividus populations in the Medes Islands (Sala \& Zabala 1996), as patterns of lower sea urchin density relative to the unprotected area nearby were not maintained over time. Furthermore, mean size of $P$. lividus did not show differences between the reserve and the unprotected area in boulders.

Sea urchin recruitment exhibits significant differences across space and time in the northwestern Mediterranean: recruitment rate may be strikingly different between very close sites (hundreds of meters; Sala \& Zabala 1996) and consecutive years (Lozano et al. 1995, Turon et al. 1995). These differences may create a dynamic mosaic in space, leading to patches with differential recruitment rates, under different predation rates, etc. These differences in historical processes which persist over time complicate the interpretation of urchin abundance patterns. Our results show that variations in abundance and population size-structure at small spatial and temporal scales may lead to misinterpretation of what is happening at larger scales.

These facts warn us again about the danger of drawing general conclusions from short-term studies (sensu Dayton \& Tegner 1984). Sala \& Zabala (1996), who monitored Paracentrotus lividus on boulders from 1992 to 1994 and carried out a predation experiment, arrived at the conclusion that fish predation played an important role in determining urchin abundance. Our results suggest that recruitment rate, shelter, migration, and other factors causing mortality should be seriously considered. All these factors are also interacting in unprotected areas, hence increases in sea urchin density should not be attributed solely to overfishing (Sala et al. 1998). Fish predation is a process that may have an absolute importance by itself (i.e. biomass of urchins eaten per unit of time and area), but whose relative importance depends on the absolute importance of other processes (such as recruitment rate). The next step would require factorial experiments with predation rate, recruitment rate, and shelter as factors to be manipulated.

Coupling of different processes might reduce the differences in community structure between areas with different levels of fishing For instance, fish predation may not be able to counteract high sea urchin recruitment, because there are other factors that help urchins to survive, such as shelters. As well, there could be spatial and temporal variations in fish predation pressure on sea urchins. It should be taken into consideration that reserves do not represent equilibrium points. Real reserves only lack human harvesting. They are, though, susceptible to oceanographic events. Although the lack of human predation within reserves may help communities to recover after disturbances, it may not prevent strong fluctuations due to strong events
Acknowledgements. We are grateful to M. Graham, A. Hobday, M. Tegner, S. Thrush, and anonymous referees for valuable comments on the manuscript, and to X. Turon for discussion. Special thanks to R. W. Emerson, who demonstrated that predation is not as important as it was expected to be. This research was supported by project number PCC 68003/9 of the Direcció General de Pesca of the Generalıtat de Catalunya

\section{LITERATURE CITED}

Azzolina JF (1988) Contribution à l'étude de la dynamique des populations de l'oursin comestible Paracentrotus lividus (Lmck). Croissance, recrutement, mortalité, migrations. Thèse doct, Univ Aix-Marseille II

Botsford LW, Castilla JC, Peterson $\mathrm{CH}$ (1997) The management of fisheries and marine ecosystems. Science 277 : 509-515

Boudouresque CF, Caltagirone A, Lefevre JR, Rico V, Semroud $R$ (1992) Macrozoobenthos de la réserve naturelle de Scandola (Corse, Méditerranée nord-occidentale). Analyse pluriannuelle de 'l'effet réserve'. in: Olivier $\mathrm{J}$, Gerardin N, Jeudy de Grissac A (eds) Impact économique des espaces côtiers protégés de Méditerranée. Sécrétariat du MEDPAN publ, Ajaccio, p 15-20

Breen PA, Carson TA, Foster JB, Stewart EA (1982) Changes in subtidal commininty structure associaled wiih Britisn Columbia sea otter transplants. Mar Ecol Prog Ser 7:13-20

Cowen RK (1983) The effect of sheephead (Semicossyphus pulcher) predation on red sea urchin (Strongylocentrotus franciscanus) populations: an experimental analysis. Oecologia 58:249-255

Dance C (1987) Patterns of activity of the sea urchin Paracentrotus lividus in Port-Cros Bay (France, Mediterranean). PSZN I: Mar Ecol 8:97-106

Dayton PK, Tegner M (1984) The importance of scale in community ecology: a kelp forest example with terrestrial analogs. In: Price PW, Slobodchikoff CN, Gaud WS (eds) A new ecology: novel approaches to interactive systems. Wiley, New York, p 457-481

Dayton PK, Thrush SF, Agardi MT, Hofman RJ (1995) Environmental effects of marine fishing. Aquat Conserv Mar Freshwat Ecosyst 5:205-232

Fenaux L, Pedrotti ML (1988) Métamorphose des larves d'échinides en pleine eau. PSZN I: Mar Ecol 9:93-107

Francour $P$, Boudouresque CF, Harmelin JG, HarmelinVivien ML, Quignard JP (1994) Are the Mediterranean waters becoming warmer? Information from biological indicators. Mar Pollut Bull 28:523-526

Frantzis A, Berthon JF, Maggiore F (1988) Relations trophiques entre les oursins Arbacia lixula el Paracentrotus lividus (Echinoidea Regularia) et le phytobenthos infralittoral superficiel dans la baie de Port-Cros (Var, France). Trav Scl Parc Nat Port-Cros 14:81-140

García-Rubies A (1997) Estudi ecologic de les poblacions de peixos litorals sobre substrat rocós a la Mediterrània Occidental: efecte de la fondària, el substrat, l'estacionalitat i la protecció. Tesi doctoral, Universitat de Barcelona

García-Rubies A, Zabala M (1990) Effects of total fishing prohibition on the rocky fish assemblages of Medes Islands Marine Reserve (NW Mediterranean). Sci Mar 54:317-328

Grosjean P, Spirlet C, Jangoux M (1996) Experimental study of growth in the echinoid Paracentrotus lividus (Lamarck, 1816) (Echinodermata). J Exp Mar Biol Ecol 201:173-184

Hay ME (1984) Patterns of fish and urchin grazing on Caribbean coral reefs: are previous results typical? Ecology 65:446-454 
Himmelman JH, Lavergne Y, Axelsen F, Cardinal A, Bourget E (1983) Sea urchins in the Saint Lawrence Estuary: their abundance, size-structure, and suitability for commercial exploitation. Can J Fish Aquat Sci 40:474-486

Kempf M (1962) Recherches d'écologie comparée sur Paracentrotus Ividus (Lmk.) et Arbacia lixula (L.). Rec Trav Stn Mar Endoume 25:47-116

Lawrence JM (1975) On the relationships between marine plants and sea urchins. Oceanogr Mar Biol Annu Rev 13. 213-286

Lawrence JM (1996) Mass mortality of echinoderms from abiotic factors. In: Jangoux M, Lawrence JM (eds) Echinoderm studies 5. AA Balkema, Rotterdam, p 103-137

Lawrence JM, Sammarco PW (1982) Elfects of feeding on the environment: Echinoidea. In: Jangoux M, Lawrence JM (eds) Echinoderm nutrition. A.A. Balkema, Rotterdam, p $499-519$

Lessios HA (1988) Mass mortality of Diadema antillarum in the Caribbean: what have we learned? Annu Rev Ecol Syst 19:371-393

Lozano J, Galera J, López S, Turón K, Palacín C, Morea G (1995) Biological cycles and recruitment of Paracentrotus lividus (Lamarck) (Echinodermata: Echinoidea) in two contrasting habitats. Mar Ecol Prog Ser 122:179-191

McClanahan TR (1994) A coral reef ecosystem-fisheries model: impacts of fishing intensity and catch selection on reef structure and processes. Ecol Model 80:1-19

McClanahan TR (1995) Status of Kenyan coral reefs. Coast Manag 23:57-76

McClanahan TR, Kurtis JD (1991) Population regulation of the rock-boring sea urchin Echinometra mathaei (de Blainville). J Exp Mar Biol Ecol 147:121-146

McClanahan TR, Muthiga NA (1989) Patterns of predation on a sea uirchin, Echinomctra mathaei (de Blainville), on Kenyan coral reefs. J Exp Mar Biol Ecol 126:77-94

McClanahan TR, Sala E (1997) A Mediterranean rockybottom ecosystem fisheries model. Ecol Model 104: $145-165$

M.Clanahan TR, Shafir SH (1990) Causes and consequences of sea urchin abundance and diversity in Kenyan coral reef lagoons. Oecologia (Berlin) 83:362-370

Palacín C, Girıbet G, Carner S, Dantart L, Turon X (in press) Low densities of sea urchins influence the structure of algal assemblages in the western Mediterranean. J Sea Res

Ros J. Romero J, Ballesteros E, Gli JM (1985) Diving in blue water. The benthos. In: Margalef R (ed) Western Mediterranean. Pergamon Press, Oxford, p 233-295

Editorial responsibility: Otto Kinne (Editor), Oldendorf/Luhe, Germany
Sala $E$ (1996) The role of fishes in the organization of a Mediterranean sublittoral community. Thèse doct, Univ A.ix-Marseille II

Sala E (1997) Fish predators and scavengers of the sea urchin Paracentrotus lividus in marine protected areas of the northwestern Mediterranean. Mar Biol 129:531-539

Sala E, Boudouresque CF (1997) The role of fishes in the organization of a Mediterranean sublittoral community. I. A.lgal communities. J Exp Mar Biol Ecol 212:25-44

Sala E, Boudouresque CF, Harmelin-Vivien M (1998\} Fishing. trophic cascades, and the structure of algal assemblages: evaluation of an old but untested paradigm. Oikos 82 : $425-439$

Sala E, Zabala M (1996) Fish predation and the structure of the sea urchin populations in the NW Mediterranean. Mar Ecol Prog Ser 140:71-81

San Martin GA (1995) Contribution à la gestion des stocks d'oursins: étude des populations et transplantations de Paracentrotus lividus à Marseille (France) et production de Loxechinus albus à Chiloe (Chili, Pacifique). Thèse doct, Univ Aix-Marseille II

Savy S (1987) Les predateurs de Paracentrotus lividus (Echinodermata). In: Boudouresque CF (ed) Colloque International sur Paracentrotus lividus et les oursins comestibles. GIS Posidonie, Marseille, p 413-423

Schiel DR, Foster MS (1986) The structure of subtidal algal stands in temperate waters. Oceanogr Mar Biol Annu Rev 24:265-307

Tegner MJ, Dayton PK (1981) Population structure, recruitment and mortality of two sea urchins (Strongylocentrotus franciscanus and $S$. purpuratus) in a kelp forest. Mar Ecol Prog Ser 5:255-268

Turon X, Giribet G, López S, Palacín C (1995) Growth and population structure of Paracentrotus lividus (Lamarck) (Echinodermata: Echinoidea) in two contrasting habitats. Mar Ecol Prog Ser 122:193-204

Underwood AJ, Fairweather PJ (1989) Supply-side ecology and benthic marine assemblages. Trends Ecol Evol 4: $16-20$

Verlaque M (1987) Relations entre Paracentrotus lividus (Lamarck) et le phytobenthos de Méditerranée occidentale. In: Boudouresque CF (ed) Colloque international sur Paracentrotus lividus et les oursins comestibles. GIS Posidonie, Marseille, p 5-36

Verlaque M, Nédélec H (1983) Biologie de Paracentrotus lividus (Lamarck) sur un substrat rocheux en Corse (Méditerranée, France): alimentation des adultes. Vie Milieu 33:191-201

Submitted: June 24, 1997; Accepted: April 8, 1998

Proofs received from author(s): June 18, 1998 